\title{
PENGARUH TAX AVOIDANCE, UKURAN PERUSAHAAN DAN PROFITABILITAS TERHADAP NILAI PERUSAHAAN DENGAN ASEAN CORPORATE GOVERNANCE SCORECARD SEBAGAI VARIABEL MODERASI
}

Muhammad Ahnaf Ammar Qushoyyi*, Suryo Nur Khabib

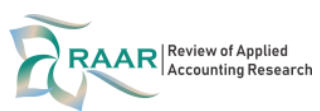

Affiliation:

Accounting Department, Institut Agama Islam Negeri Salatiga,

Indonesia

*Correspondence:

Ahnaf.amar00@gmail.com

Article Process:

Submitted:

January 24, 2022

Reviewed:

February 2, 2022

Revised:

February 6, 2022

Accepted:

February 10, 2022

Published:

February 15, 2022

Citation:

Qushoyyi. Muhammad Ahnaf

Ammar, Suryo Nur Khabib.

(2022). Pengaruh Tax Avoidance,

Ukuran Perusahaan Dan

Profitabilitas Terhadap Nilai

Perusahaan Dengan Asean

Corporate Governance Scorecard

Sebagai Variabel Moderasi.

RAAR: Review of Applied

Accounting Research, 2 (1), 263 278.

Office Address:

Jl. K.H. Ahmad Dahlan,

Dukuhwaluh, Kec.

\begin{abstract}
ABSTRAK
Penelitian ini dilatar belakangi oleh menariknya nilai perusahaan karena menggambarkan kondisi perusahaan yang dapat mempengaruhi pandangan investor terhadap perusahaan. Tingginya kemakmuran pemegang saham bisa dilihat dari nilai perusahaan. Pada awalnya perusahaan didirikan dengan tujuan untuk memaksimalkan kekayaan pemilik atau pemegang saham. Meningkatkan nilai perusahaan mempunyai arti meningkatkan pendapatan dan menimalisir biaya yang keluar dengan tujuan menghasilkan laba yang maksimal. Tujuan penelitin ini untuk mengetahui pengaruh tax avoidance, ukuran perusahaan, dan profitabiltas terhadap niali perusahaan dengan ASEAN corporate governance scorecard sebagai variabel moderating pada perusahaan lq 45 pada tahun 2018-2020. Metode pengumpulan data penelitian dengan ini menggunakan data sekunder berasal dari Annual Report perusahaan anggota rutin lq 45 pada tahun 2018-2020. Hasil penelitian variabel tax avoidance dan uuran perusahaan tidak mempengaruhi nilai perusahaan, sedangkan profitabilitas mempengaruhi nilai perusahaan. Kemudian, tax avoidance terhadap nilai perusahaan dan ukuran perusahaan terhadap nilai perusahaan tidak mampu dimoderasi ASEAN corporate governance scorecard, sedangkan profitabilitas terhadap nilai perusahaan mampu dimoderasi ASEAN corporate governance scorecard.
\end{abstract}

Kata Kunci: Tax avoidance, ukuran perusahaan, profitabilitas, ASEAN corporate governance scorecard

\begin{abstract}
This research is motivated by the attractive value of the company because it describes the condition of the company that can affect investors' views of the company. The high prosperity of shareholders can be seen from the value of the company. Initially the company was founded with the aim of maximizing the wealth of the owners or shareholders. Increasing the value of the company means increasing revenue and minimizing costs with the aim of generating maximum profit. The purpose of this study was to determine the effect of tax avoidance, firm size, and profitability on firm value with the ASEAN corporate governance scorecard as a moderating variable in IQ 45 companies in 2018-2020. This research data collection method uses secondary data derived from the Annual Report of routine member companies lq 45 in 2018-2020. The results of the research on tax avoidance variables and firm size do not affect firm value, while profitability affects firm value. Then, tax avoidance on firm value and firm size on firm value cannot be moderated by the ASEAN corporate governance scorecard, while profitability on firm value can be moderated
\end{abstract}


Kembaran, Kabupaten Banyumas, Jawa Tengah 53182

e-ISSN : 2807-8969 by the ASEAN corporate governance scorecard.

Keywords: Tax avoidance, ukuran perusahaan, profitabilitas, ASEAN corporate governance scorecard

\section{PENDAHULUAN}

Nilai perusahaan sangat menarik diteliti karena nilai perusahaan menggambarkan kondisi perusahaan yang dapat mempengaruhi pandangan investor terhadap perusahaan. Tingginya kemakmuran pemegang saham bisa dilihat dari nilai perusahaan. Pada awalnya perusahaan didirikan dengan tujuan untuk memaksimalkan kekayaan pemilik atau pemegang saham. Meningkatkan nilai perusahaan mempunyai arti meningkatkan pendapatan dan menimalisir biaya yang keluar dengan tujuan menghasilkan laba yang maksimal.

Tabel 1. Data Fenomena Nilai Perusahaan

\begin{tabular}{|c|c|c|c|}
\hline Global Brand Owner & $\begin{array}{c}\text { 2020 } \\
\text { Rank }\end{array}$ & $\begin{array}{c}2019 \text { acts } \\
\text { (US\$ } \\
\text { Million) }\end{array}$ & $\begin{array}{c}\text { 2020 acts } \\
\text { (US\$ } \\
\text { Million) }\end{array}$ \\
\hline Tokopedia PT & 1 & 7,439 & 11,683 \\
\hline $\begin{array}{c}\text { Seven \& I Holding Co } \\
\text { Ltd }\end{array}$ & 2 & 12,939 & 11,532 \\
\hline Sea Ltd & 3 & 5,157 & 8,739 \\
\hline Tesco Plc & 4 & 6,929 & 6,504 \\
\hline $\begin{array}{c}\text { Sumber Alfaria Trijaya } \\
\text { Tbk PT }\end{array}$ & 5 & 6,210 & 6,437 \\
\hline Salim Group & 6 & 5,832 & 6,221 \\
\hline $\begin{array}{c}\text { Alibaba Group Holding } \\
\text { Ltd }\end{array}$ & 7 & 3,373 & 5,599 \\
\hline Central Group & 8 & 6,307 & 5,543 \\
\hline SM Retail Inc & 9 & 6,312 & 5,406 \\
\hline Mobile Word JSC & 10 & 4,387 & 4,474 \\
\hline Bukalapak.com PT & 11 & 2,432 & 3,657 \\
\hline Mercury Drug Corp & 12 & 2,967 & 3,516 \\
\hline Puregold Price Club Inc & 13 & 2,874 & 3,418 \\
\hline $\begin{array}{c}\text { Daily Farm International } \\
\text { Holdings Ltd }\end{array}$ & 14 & 3,311 & 3,203 \\
\hline Big C Supercenter PCL & 15 & 3,405 & 3,006 \\
\hline
\end{tabular}

\section{Sumber: Firma Riset Global Euromonitor International}

Deskripsi dari data diatas didapatkan bahwa rata-rata perusahaan mengalami kenaikan nilai transaksi yang akan merubah harga saham. Sehingga, hal tersebut berpengaruh positif terhadap nilai perusahaan. Dari laporan tersebut, Tokopedia mengungguli Seven \& I Holding Co. Ltd. di peringkat kedua dengan nilai transaksi 11,53 juta dollar AS. Sementara di posisi ketiga ada Sea Ltd. perusahaan Singapura yang merupakan induk dari Shopee, dengan nilai transaksi 8,73 juta dollar AS. Pandemi Covid-19 mempengaruhi pola belanja masyarakat dalam satu tahun terakhir ini. Beberapa marketplace dan perusahaan ritel asal Indonesia seperti Tokopedia, Alfamart, Salim Group, dan Bukalapak mengalami lonjakan transaksi. Dari Riset Euromonitor International dalam laporannya menyebutkan, 4 perusahaan tersebut masuk dalam 15 besar perusahaan ritel terbesar

Asia tenggara. "Tokopedia ini juga menempati posisi pertama pemain retail di Indonesia sekaligus di daerah Asia Tenggara," demikian dikutip dari laporan Euromonitor International, Jumat 8 Oktober 2021 (Dewi, 2021). ASEAN corporate governance scorecard memiliki pengaruh negatif 
signifikan yang menjadi moderator terhadap hubungan tax avoidance dan nilai perusahaan (Yee et al., 2018). Tetapi, hasil penelitian lain menunjukkan good corporate governance berpengaruh positif signifikan, good corporate governance merupakan variabel moderasi yang memperkuat pengaruh ukuran perusahaan pada nilai perusahaan. Hasil penelitian serupa ditemukan dalam penelitian sebelumnya yang dilakukan oleh Lestari \& Wirawati (2018); (Wasista \& Putra, 2019).

Tax avoidance memberikan pengurangan nilai perusahaan. Hasil penelitian ini sejalan dengan penelitian yang dilakukan oleh Ampriyanti dan lely (2016) yang menyatakan negatif signifikan tax avoidance terhadap nilai perusahaan. Namun, tidak sesuai dengan penelitian yang dilakukan oleh Jonathan dan Vivi (2016); (Azhar, 2017), hasil penelitian lain juga menunjukkan bahwa tax avoidance yang dilakukan atas perusahaan sampel tidak berpengaruh pada nilai perusahaan (Inanda et al., 2018). Berpengaruh negatif signifikan ukuran perusahaan terhadap nilai perusahaan LQ 45 (Zoebaedi \& Warsono, 2019), sedangkan hasil lain menunjukkan berpengaruh positif signifikan ukuran perusahaan terhadap nilai perusahaan (Wiksuana \& Wulandari, 2017).

Nilai perusahaan dipengaruhi secara negatif signifikan oleh profitabilitas (Kusna \& Setijani, 2018), sedangkan Hasil penelitian menunjukkan bahwa nilai perusahaan dipengaruhi secara positif dan signifikan oleh profitabilitas (Martha et al., 2018). Pembeda dari penelitian terdahulu, pertama: pengungkapan dengan studi kasus Index Saham Syariah apakah hasilnya akan berbeda dibanding Index Saham Konvensional serta berdasarkan tahun yang lebih baru, kedua: Menambahkan variabel moderasi ASEAN corporeate governance scorecard

\section{TINJAUAN PUSTAKA}

\section{Singnaling Theory}

Theory signaling pertama kali dikemukakan oleh Spence (1973) yang menjelaskan bahwa pihak pengirim (pemilik informasi) memberikan suatu isyarat atau sinyal berupa informasi yang mencerminkan kondisi perusahaan yang bermanfaat bagi pihak penerima (investor). Adanya informasi asimetris perusahaan (manajer) dan pihak luar (investor) mengakibatkan munculnya dorongan dalam sinyal. Signaling theory dalam mengurangi informasi asimetris perusahaan memberi tindakan sebagai sinyal. Brigham dan Houston (2001), tindakan perusahaan memberi petunjuk investor bagaimana manajer memandang prospek perusahaan dinamakan isyarat atau sinyal. Pihak luar diberikan informasi keuangan sebagai sinyal, bisa positif maupun negatif. Brigham dan Houston (2011:184) menyatakan bahwa sinyal adalah suatu tindakan yang diambil oleh manajemen perusahaan yang memberikan petunjuk bagi investor tentang bagaimana manajemen memandang prospek perusahaan (Israel, 2018).

Nilai laba bersih yang dilaporkan pada laporan keuangan merupakan sinyal yang diberikan perusahaan. Tax avoidance yang menghasilkan informasi laba bersih tinggi diharapkan menjadi sinyal positif bagi investor, dengan dampak positif nilai perusahaan tercermin di pasar modal atas peningkatan saham. Tax avoidance yang menghasilkan informasi nilai laba bersih dapat menjadi sinyal negatif terhadap nilai perusahaan. Wang (2010) mengungkapkan bahwa bagi pemegang saham, biaya tambahan masa datang akan timbul akibat tax avoidance. Biasanya berupa perencanaan pajak dan biaya lain, seperti biaya pemeriksaan dan biaya denda (Inanda et al., 2018).

2. Nilai Perusahaan

Rumus pengukuran nilai perusahaan menggunakan Tobin's: $\mathbf{Q}=\mathbf{M V E}+\mathbf{D} / \mathbf{B V E}+\mathbf{D}$

Penjelasan dari rumus: Nilai perusahaan $=\mathrm{Q}$, nilai pasar ekuitas (Hasil perkalian harga saham penutupan dengan jumlah saham yang beredar) = MVE, nilai buku dari ekuitas (Equity Book Value) = BVE, total hutang (Wardani \& Juliani, 2018).

\section{Tax Avoidence}


Pengukuran tax avoidance dilakukan menggunakan rumus: CASH ETR = pembiayaan pajak / laba sebelum pajak (Rajagukguk et al., 2020).

4. Ukuran Perusahaan

Ukuran perusahaan: Ln (Total aktiva) (Rajagukguk et al., 2020).

5. Profitabilitas

Rumus pengukuran profitabilitas : ROA = earning after tax (laba bersih tahun berjalan)/total assets $\mathrm{x}$ 100\% (Hardiningsih et al., 2018).

6. ASEAN Corporate Governance Scorecard

Dihitung menggunakan variabel dummy jika ada mempunyai nilai 1 jika tidak ada mempunyai nilai 0 (Putra, 2018)

\section{HIPOTESIS PENELITIAN}

\section{Pengaruh Tax Avoidance terhadap Nilai Perusahaan.}

Signaling theory dalam mengurangi informasi asimetris perusahaan memberi tindakan sebagai sinyal. Brigham dan Houston (2001), tindakan perusahaan memberi petunjuk investor bagaimana manajer memandang prospek perusahaan dinamakan isyarat atau sinyal. Pihak luar diberikan informasi keuangan sebagai sinyal, bisa positif maupun negatif. Menurut theory signaling jika terlalu menaikkan tax avoidance maka yang terjadi malah menjatuhkan nilai perusahaan. Karena mengurangi sebuah kandungan informasi yang diberikan sehingga mempengaruhi keputusan dalam memberikan nilai perusahaan.

Tax avoidance berpengaruh negatif terhadap nilai perusahaan jika manajer melakukan aktivitas tax avoidance guna menutupi oportunistik manajer dengan memanipulasi laba yang dilaporkan dan manajer kurang transparan dalam menjalankan operasional perusahaan sesuai dengan yang dikatakan Ningtias (2015:34). Anggoro dan Septiani (2015;3) mengatakan perilaku tersebut tentunya akan mengurangi kandungan informasi yang disajikan, dan akhirnya akan mempengaruhi keputusan investor dalam memberikan nilai pada perusahaan. Jadi, semakin tinggi tingkat tax avoidance yang dilakukan oleh manajer maka akan semakin berkurang kandungan informasi dari laporan keuangan, dengan semakin berkurangnya kandungan informasi yang disajikan maka akan berdampak pada semakin rendahnya nilai perusahaan (Wardani \& Juliani, 2018).

Penelitian ini sejalan dengan penelitian yang dilakukan oleh (Yee et al., 2018) yang menyatakan memeriksa hubungan antara tax avoidance dan nilai setelah pajak perusahaan Malaysia dalam kerangka keagenan dan menemukan bahwa tax avoidance berhubungan negatif signifikan dengan penilaian perusahaan. Kemudian penelitian yang dilakukan oleh (Rajagukguk et al., 2020) juga menyatakan bahwa tax avoidance (Cash ETR) tax avoidance berpengaruh negatif signifikan terhadap nilai perusahaan.

H1: Tax avoindance berpengaruh negatif terhadap nilai perusahaan.

\section{Pengaruh Ukuran Perusahaan terhadap Nilai Perusahaan.}

Signaling theory mengungkapkan tax avoidance yang menghasilkan Informasi nilai laba bersih dapat menjadi sinyal negatif terhadap nilai perusahaan. Wang (2010) mengungkapkan bahwa

\section{RAAR}

Vol.2 No.1 bagi pemegang saham, biaya tambahan masa datang akan timbul akibat tax avoidance. Biasanya berupa perencanaan pajak dan biaya lain, seperti biaya pemeriksaan dan biaya denda (Inanda et al., 2018). Menurut theory Signaling perusahaan bukanlah hanya beroperasi untuk kepentingan sendiri, Namun juga harus memberikan manfaat kepada stakeholdernya seperti pemegang saham. Perusahaan dengan ukuran perusahaan yang tinggi akan berusaha menyampaikan lebih 
banyak informasi atau segala laporan dengan lebih detail. Sehingga, menambah kepercayaan investor yang menjadikan sinyal positif yang akhirnya terjadi peningkatan nilai perusahaan.

Ukuran perusahaan yang besar menunjukkan perusahaan mengalami perkembangan sehingga investor akan merespon positif dan nilai perusahaan akan meningkat. Pangsa pasar relatif menunjukkan daya saing perusahaan lebih tinggi dibanding pesaing utamanya. Investor akan merespon positif sehingga nilai perusahaan akan meningkat. Perusahaan yang memiliki total aktiva dengan jumlah besar atau disebut dengan perusahaan besar akan lebih banyak mendapatkan perhatian dari investor, kreditor maupun para pemakai informasi keuangan lainnya dibandingkan dengan perusahaan kecil.

Penelitian ini sejalan dengan penelitian yang dilakukan oleh beberapa peneliti-peneliti berikut ini: Berpengaruh positif signifikan ukuran perusahaan terhadap nilai perusahaan (Hardiningsih et al., 2018), berpengaruh positif tetapi tidak signifikan ukuran perusahaan terhadap nilai perusahaan (Holly, 2018), berpengaruh positif dan signifikan ukuran perusahaan terhadap nilai perusahaan (S. Dewi, 2018), berpengaruh positif signifikan ukuran perusahaan terhadap nilai perusahaan (Kusna \& Setijani, 2018), berpengaruh positif dan tidak signifikan ukuran perusahaan terhadap nilai perusahaan (D. Dewi \& Sudiartha, 2017), berpengaruh positif dan signifikan ukuran perusahaan terhadap nilai perusahaan (Wiksuana \& Wulandari, 2017), berpengaruh positif dan tidak signifikan ukuran perusahaan terhadap nilai perusahaan (Widyantari \& Yadnya, 2017).

H2: Ukuran perusahaan berpengaruh positif terhadap nilai perusahaan.

\section{Pengaruh Profitabilitas terhadap Nilai Perusahaan}

Signaling theory mengungkapkan nilai laba bersih yang dilaporkan pada laporan keuangan merupakan sinyal yang diberikan perusahaan. Tax avoidance yang menghasilkan informasi laba bersih tinggi diharapkan menjadi sinyal positif bagi investor, dengan dampak positif nilai perusahaan tercermin di pasar modal atas peningkatan saham. Menurut theory signaling menyatakan tax avoidance memberikan informasi laba bersih yang tinggi diharapkan menjadi sinyal positif. Sinyal itu ditujukan kepada investor, sehingga berdampak positif pada nilai perusahaan.

Kemampuan perusahaan dalam menghasilkan profit atau laba dinamakan profitabilitas. Perusahaan yang dapat membukukan profit tinggi maka perusahaan tersebut dinilai berhasil dalam menjalankan usaha. Perusahaan yang dapat menciptakan profit atau laba besar berarti perusahaan dapat menciptakan pendanaan internal bagi perusahaan sendiri. Semakin besar profitabilitas yang dapat dihasilkan oleh perusahaan maka investor akan semakin senang untuk melakukan investasi dalam perusahaan tersebut (Holly, 2018).

Penelitian ini sejalan dengan penelitian yang dilakukan oleh peneliti-peneliti berikut ini: Nilai perusahaan dipengaruhi secara positif dan signifikan oleh profitabilitas (Martha et al., 2018), berpengaruh positif dan signifikan profitabilitas terhadap nilai perusahaan (Holly, 2018), pengaruh positif signifikan profitabilitas terhadap nilai perusahaan (Lumolu et al., 2018), berpengaruh positif signifikan ROA terhadap nilai perusahaan (Hardiningsih et al., 2018), berpengaruh positif signifikan profitabilitas terhadap nilai perusahaan (Mawati et al., 2017), pengaruh positif signifikan profitabilitas terhadap nilai perusahaan (Nurminda et al., 2017), berpengaruh positif dan signifikan profitabilitas terhadap nilai perusahaan (Wiksuana \& Wulandari, 2017), secara parsial berpengaruh signifikan dan mempunyai arah yang positif profitabilitas terhadap nilai perusahaan (Suwardika \& Mustanda, 2017), berpengaruh positif dan signifikan profitabilitas terhadap nilai perusahaan (Widyantari \& Yadnya, 2017). 


\section{Pengaruh Tax Avoidance terhadap Nilai Perusahaan di Moderasi ASEAN Corporate Governance Scorecard.}

85 Signaling theory dalam mengurangi informasi asimetris perusahaan memberi tindakan sebagai sinyal. Brigham dan Houston (2001), tindakan perusahaan memberi petunjuk investor bagaimana manajer memandang prospek perusahaan dinamakan isyarat atau sinyal. Pihak luar diberikan informasi keuangan sebagai sinyal, bisa positif maupun negatif. Dapat diartikan berarti butuh tata pengelolaan untuk penghindaran pajak terhadap nilai perusahaan. Menurut theory Signaling jika terlalu menaikkan tax avoidance maka yang terjadi malah menjatuhkan nilai perusahaan. Karena mengurangi kandungan informasi yang diberikan sehingga mempengaruhi keputusan dalam memberikan nilai perusahaan. Hal tersebut tidak berlaku untuk perusahaan yang mempunyai corporate governance yang baik justru tax avoidance yang tinggi bisa meningkatkan nilai. Namun, perusahaan yang memiliki corporate governance yang tidak baik juga akan menghasilkan berkurangnya nilai perusahaan.

Desai dan Dharmapala (2006) mengemukakan bahwa dampak insentif daya tinggi pada perlindungan pajak dapat bervariasi dan tergantung pada corporate governance perusahaan. Desai dam Dharmapala (2009) mengemukakan bahwa penghindaran pajak akan meningkatkan nilai perusahaan bagi perusahaan dengan corporate governance yang baik dan sebaliknya untuk perusahaan yang corporate governancenya buruk. Kemudian Chen, Hu, Wang \& Tang (2014) menemukan bahwa perilaku tax avoidance cenderung menurunkan nilai perusahaan akibat peningkatan biaya keagenan yang diakibatkan oleh perusahaan yang tidak memiliki corporate governance yang baik (Yee et al., 2018).

Penelitian ini sejalan dengan yang diteliti oleh (Yee et al., 2018) yang menyatakan bahwa kekuatan mekanisme corporate governance memiliki pengaruh negatif signifikan yang menjadi moderator terhadap tax avoidance dan Nilai Perusahaan.

H4: ASEAN corporate governance scorecard tidak mampu memoderasi tax avoindence terhadap nilai perusahaan.

\section{Pengaruh Ukuran Perusahaan terhadap Nilai Perusahan di Moderasi ASEAN Corporate Governance Scorecard.}

Signaling theory mengungkapkan tax avoidance yang menghasilkan Informasi nilai laba bersih dapat menjadi sinyal negatif terhadap nilai perusahaan. Wang (2010) mengungkapkan bahwa bagi pemegang saham, biaya tambahan masa datang akan timbul akibat tax avoidance. Biasanya berupa perencanaan pajak dan biaya lain, seperti biaya pemeriksaan dan biaya denda (Inanda et al., 2018). Dapat di artikan bahwa ukuran perusahaan disini sebenarnya membutuhkan corporate governance yang baik sehingga disini juga memberikan klasifikasi mengenai ukuran perusahaan yang bisa liat dengan berbagai cara seperti total asset dan sebagainya.

Menurut theory signaling perusahaan tidak saja beroperasi guna kepentingan pribadi, tetapi juga bisa memberi manfaat kepada stakeholdernya seperti pihak pemegang saham. Maka dari itu, dibutuhkan corporate governance yang baik untuk mendapatkan kepercayaan investor karena perusahaan dengan ukuran perusahaan yang tinggi akan berusaha menyampaikan lebih banyak informasi atau segala laporan dengan lebih detail. Dari hal tersebut, menjadikan sinyal positif yang akhirnya terjadi peningkatan nilai perusahaan.

\section{RAAR}

Vol.2 No.1

Good corporate governance merupakan suatu sistem yang mengatur bagaimana organisasi dioperasikan dan dikontrol dengan baik. Good corporate governance lebih condong pada serangkaian pola perilaku perusahaan yang diukur melalui kinerja, pertumbuhan, struktur pembiayaan, ukuran, perlakuan terhadap para pemegang saham. Mekanisme corporate governance juga memberikan suatu struktur yang memfasilitasi penentuan sasaran dari suatu perusahaan dan sebagai sarana untuk menentukan teknik monitoring. Menurut Rahadianti 
(2011), alasan utama implementasi corporate governance merupakan suatu bentuk lain penegakan etika bisnis dan etika kerja yang sudah lama menjadi komitmen perusahaan dan implementasi corporate governance berhubungan dengan peningkatan citra perusahaan. Perusahaan yang mempraktikkan corporate governance akan mengalami perbaikan citra dan peningkatan nilai perusahaan.

Penelitian ini sejalan dengan apa yang diteliti oleh (Wasista \& Putra, 2019) good corporate governance berpengaruh positif signifikan, good corporate governance merupakan variabel moderasi yang memperkuat pengaruh ukuran perusahaan pada nilai perusahaan. Hasil penelitian serupa ditemukan dalam penelitian sebelumnya yang dilakukan oleh Lestari \& Wirawati (2018).

H5: ASEAN corporate governance scorecard berpengaruh memoderasi ukuran perusahaan terhadap nilai perusahaan.

\section{Pengaruh Profitabilitas terhadap Nilai Perusahaan di Moderasi ASEAN Corporate Governance Scorecard.}

Signaling theory mengungkapkan nilai laba bersih yang dilaporkan pada laporan keuangan merupakan sinyal yang diberikan perusahaan. Tax avoidance yang menghasilkan informasi laba bersih tinggi diharapkan menjadi sinyal positif bagi investor, dengan dampak positif nilai perusahaan tercermin di pasar modal atas peningkatan saham. Dapat diartikan bahwa perlu adanya corporate governance pada laporan keuangan yang berkaitan laba agar tetap mempertahankan nilai perusahaan. Menurut theory signaling hak pemegang saham tentang nilai laba bersih yang dilaporkan harus mendapat dukungan dari sebuah corporaate governance yang baik. Diharapkan, bisa berwujud sinyal positif untuk investor, sehingga berdampak positif pada nilai perusahaan.

Hal ini menunjukkan bahwa peran pemegang saham tidak akan berpengaruh terhadap profitabilitas jika hak mereka tidak didukung oleh kondisi corporate governance yang baik oleh perusahaan. Asia Pembangunan Bank (2016a) mengungkapkan salah satu ukuran corporate governance khususnya di Negara-negara ASEAN adalah ASEAN corporate governance scorecard. Scorecard corporate governance perusahaan ASEAN menunjukkan praktik corporate governance perusahaan di bidang hak pemegang saham, perlakuan yang adil terhadap pemegang daham, peran pemangku kepentingan, pengungkapan dan transparansi, dan tanggung jawab dewan (Putra, 2018).

Penelitian ini sejalan dengan apa yang diteliti oleh (Putra, 2018) yang menyatakan bahwa ACGS yang baik mengarah ke profitabilitas yang tinggi.

H6: ASEAN corporate governance scorecard berpengaruh memoderasi profitabilitas terhadap nilai perusahaan.

\section{METODOLOGI PENELITIAN}

Metode pada penelitian ini menggunakan penelitian kunatitatif. Diteliti pada perusahaan ISSI (Index Saham Syariah Indonesia) jangka waktu tahun 2018 - 2020 pada indeks saham LQ45. Populasi yang digunakan yaitu seluruh perusahaan yang rutin menjadi anggoota di Indeks Saham Syariah Indonesia (ISSI) pada indeks saham LQ45 2018-2020. Jumlahnya terdapat 37 perusahaan. Maka, 37 perusahaan selama 3 tahun laporan total menjadi 111. Sampel penelitian menggunakan taraf kesalahan 5\% sebagai berikut:

Tabel 2. rumus solvin

\begin{tabular}{c|c|c}
\hline Populasi & Taraf Kesalahan & Sampel \\
\hline 111 & $5 \%$ & 86,8885 \\
\hline
\end{tabular}


Jadi, dari anggota populasi yang diambil sebagai sampel adalah sebanyak 86,8885 laporan

87 perusahaan. Berikut kriteria pengambilan sampel dalam penelitian ini:

1. Aktif memberikan laporan keuangan atau publikasi data periode $2018-2020$

2. Tidak memiliki data extreme

Sampel yang digunakan berdasarkan populasi diatas yaitu 87 laporan keuangan. Berdasarkan dari data yang diambil langsung dari situs resmi dan diseleksi mendapatkan 32 laporan keuangan dalam 3 tahun menjadi 96 laporan keuangan dari 37 anggota rutin perusahaan yang terdaftar pada indeks LQ45 jangka waktu 2018-2020. Maka, itu yang kemudian dijadikan sampel dalam penelitian ini.

Dalam pengolahan data menggunakan moderated regression analysis. Software pengolahanya menggunakan SPSS versi 26. Analisis moderated regression analysis dilakukan berguna menganalisis hipotesis dalam penelitian ini dan tingkat signifikansi yang digunakan sebesar 5\% atau 0,05 . Pada penelitian ini rumus yang didapat yaitu:

$\mathrm{Y}=\mathrm{a}+\mathrm{b} 1 \mathrm{X1}$ (tax avoidance) + b2X2 (ukuran perusahaan) + b3X3 (profitabilitas) $+\mathrm{b} 4 \mathrm{Z}$ (ASEAN corporate governance scorecard $)+\mathrm{b} 5 \mathrm{X} 1 \mathrm{Z}+\mathrm{b} 6 \mathrm{X} 2 \mathrm{Z}+\mathrm{b} 7 \mathrm{X3Z}+\mathrm{e}$

(Wasista \& Putra, 2019).

Anggota populasi yang diambil sebagai sampel adalah sebanyak 86,8885 laporan perusahaan. Berikut kriteria pengambilan sampel dalam penelitian ini:

3. Aktif memberikan laporan keuangan atau publikasi data periode 2018-2020

4. Tidak memiliki data extreme

\section{HASIL DAN PEMBAHASAN}

1. Hasil penelitian

A. Deskripsi Obyek Penelitian

1. Analisis Deskriptif

Tabel 3.hasil analisis deskriptif

\begin{tabular}{lrrrrr}
\hline & \multicolumn{5}{c}{ Deskripsi statistik } \\
\cline { 2 - 6 } \multicolumn{1}{c}{ Variabel } & $\mathrm{N}$ & Minimal & Maksimal & Rata-rata & Std. Dev \\
\hline Tax avoidance (X1) & 96 & .00 & .51 & .2319 & .10063 \\
Ukuran perusahaan (X2) & 96 & 29.45 & 34.80 & 31.9471 & 1.25820 \\
Profitabilitas (X3) & 96 & -.01 & .19 & .0409 & .03841 \\
Nilai perusahaan (Y) & 96 & .78 & 5.08 & 1.6731 & .96598 \\
ASEAN corporate & 96 & 0 & 1 & .69 & .466 \\
governance scorecard (Z) & & & & & \\
$\quad$ Valid N & 96 & & & & \\
\hline
\end{tabular}

Berdasarkan hasil statistik deskriptif pada tabel 4.2, bisa disimpulkan terdapat 96 jumlah sampel yang berasal dari laporan keuangan selama 3 tahun di setiap variabel yang diteliti. Nilai perusahaan (Y) memiliki nilai rata-rata 1,6731, nilai terendah 0,78 diperoleh ADRO 2020, nilai tertinggi 5,08 diperoleh SCMA 2018, dengan standar deviasi 0,96598. Tax avoidance (X1) memiliki nilai rata-rata 0,2319 , nilai terendah 0,00 diperoleh BSDE 2020, nilai tertinggi 0,51 diperoleh BRPT 2020, dengan nilai standar deviasi 0,10063. Ukuran perusahaan (X2) memiliki nilai rata-rata 31,9471, nilai terendah 29,45 diperoleh SCMA 2018 dan 2019, nilai tertinggi 34,80 diperoleh BBRI 2019, dengan nilai standar deviasi 1,25820. Profitabilitas (X3) memiliki nilai rata-rata 0,0409 , nilai terendah $-0,01$ diperoleh INCO 2020, nilai tertinggi 0.19 diperoleh SCMA 2019, dengan standar deviasi 0,03841. ASEAN corpotare governance scorecard memiliki nilai rata-rata 0,69 , nilai terendah 0 , nilai tertinggi 1 , dengan standar deviasi 0,466. 


\section{B. Uji stasioneritas}

Tabel 4. hasil uji stasioner

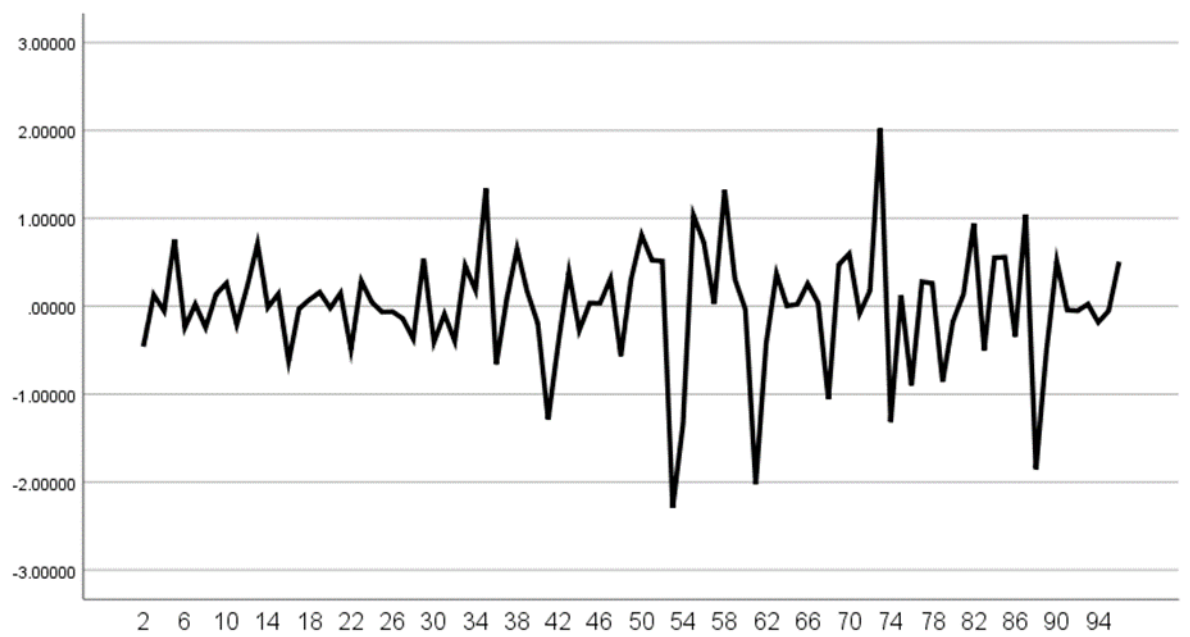

Berdasarkan hasil uji stasioner pada tabel 4.3, bisa disimpulkan semua data memiliki probabilitas 0.0000 di bawah <0,05. Penilaian menggunakan Augmented Dickey Fuller (ADF). Dilihat dari hal tersebut memiliki arti bahwa datanya stasioner.

C. Uji asumsi klasik

1. Normalitas

Tabel 5. hasil uji normalitas

\begin{tabular}{llr}
\hline & & Unstandardized Residual \\
\cline { 3 - 3 } Monte Carlo Sig. (2-tailed) & Sig. & .142 \\
\hline
\end{tabular}

Berdasarkan hasil uji normalitas one-sample kolmogorov-smirnov test tabel 4.4, dapat dilihat nilai Monte Carlo Sig. (2-tailed) bernilai 0,142. Sehingga, dapat diambil kesimpulan nilainya melebihi 0,05 itu artinya datanya normal.

2. Multikolinieritas

Tabel 6. hasil uji multikolinieritas

\begin{tabular}{lcr}
\hline & Tolerance & VIF \\
\cline { 2 - 3 } Tax avoidance (X1) & 0.933 & 1.072 \\
Ukuran perusahaan (X2) & 0.817 & 1.225 \\
Profitabilitas (X3) & 0.799 & 1.252 \\
ASEAN corporate governance scorecard $(Z)$ & 0.877 & 1.14 \\
\hline
\end{tabular}

Berdasarkan uji multikoinieritas pada tabel 4.5, dapat disimpulkan bahwa seluruh variabel memiliki nilai toleransi diatas 0,1 dan nilai variance inflation factor dibawah 10 itu artinya model terbebas dari multikolinieritas.

3. Heteroskedastisitas 
Tax avoidance (X1)

Ukuran perusahaan (X2)

Profitabilitas (X3)

ASEAN corporate governance

scorecard $(\mathrm{Z})$
Unstandardized residual

Sig. (2-tailed) 0.333

Sig. (2-tailed) 0.107

Sig. (2-tailed) 0.179

Sig. (2-tailed) 0.621

Berdasarkan uji spearman rho pada tabel 4.6, Variabel tax avoidance, ukuran perusahaan, profitabilitas dan ASEAN corporate governance scorecard mempunyai nilai signifikansi lebih besar dari 0,05 . Karena semua variabel mempunyai nilai signifikansi yang lebih besar dari 0,05 itu artinya dari hasil uji spearman rho diatas dapat disimpulkan tidak terjadi heteroskedastisitas. Tidak terdapat heteroskedastisitas apabila diatas level signifikan yaitu $\mathrm{p}$ lebih dari 0,05 , sedangkan terdapat heteroskedastisitas apabila dibawah level signifikan yaitu $\mathrm{p}$ kurang dari 0,05 (Ambarwati \& Kabib, 2021).

\section{Hasil Uji hipotesis}

1. Pengujian hipotesis mengunakan regresi sederhana a) Uji Koefisien Determinasi (Adjusted $R^{2}$ )

Tabel 8. hasil uji koefisien determinasi (Adjusted $\mathrm{R}^{2}$ )

\begin{tabular}{cccr}
\hline $\mathrm{R}$ & R Square & $\begin{array}{c}\text { Adjusted R } \\
\text { Square }\end{array}$ & \multicolumn{2}{c}{ Std. Error of the Estimate } \\
\hline $.675^{\mathrm{a}}$ & 0.456 & 0.438 & 0.72401 \\
\hline
\end{tabular}

Berdasarkan uji koefisien determinasi di atas, memiliki nilai Adjusted $R$ Square 0.438 atau $43,8 \%$ sisanya $56,2 \%$. Sehingga, dapat disimpulkan bahwa variabel independen yang terdiri dari tax avoidance, ukuran perusahaan, dan profitabilitas dapat menjelaskan variabel dependen $43,8 \%$. Sedangkan, 56,2\% dijelaskan oleh variabel lain yang tidak terdapat dalam model regresi ini.

b) Uji F (Simultan)

Tabel 9. hasil uji F

\begin{tabular}{lrrrrr}
\hline & Sum of Squares & \multicolumn{1}{c}{ df } & Mean Square & F & Sig. \\
\cline { 2 - 6 } Regression & 40.421 & 3 & 13.474 & 25.074 & $.000^{\mathrm{b}}$ \\
Residual & 48.226 & 92 & 0.524 & & \\
Total & 88.646 & 95 & & & \\
\hline
\end{tabular}

Berdasarkan uji F pada tabel 4.8, memiliki nilai uji signifikan 0,000. Nilai uji signifikan lebih kecil dari 0,05. Sehingga, model regresi dapat menjelaskan hubungan independen dan dependen dengan sangat signifikan. Semua variabel independenya mulai tax avoidance, ukuran perusahaan sampai profitabilitas secara bersama-sama memiliki pengaruh terhadap nilai perusahaan. Dengan demikian, model dan teori sangat cocok karena sangat sesuai dengan kerangka konseptual.

c) Uji T (Parsial)

Tabel 10. Hasil uji T

RAAR

Vol.2 No.1
(Constant)

Tax avoidance $(\mathrm{X} 1)$

Ukuran perusahaan (X2)

Profitabilitas (X3)

B Std. Error

$\begin{array}{rrrr}5.439 & 2.111 & 2.576 & 0.012 \\ 0.614 & 0.743 & 0.827 & 0.411 \\ -0.141 & 0.065 & 2.169 & 0.033 \\ 14.32 & 2.136 & 6.703 & 0\end{array}$


Berdasarkan uji T pada tabel 4.6 mendapatkan persamaan model regresi sederhana dengan signifikansi $0,05(5 \%)$ sebagai berikut: Nilai perusahaan $=5,439+0,614 \mathrm{X} 1-0,141 \mathrm{X} 2+$ $14,32 \times 3+\mathrm{e}$

Nilai konstanta 5,439 tidak akan berubah jika tidak ada perubahan dari variabel independen, jika tax avoidance naik 1 satuan maka nilai perusahaan akan naik 0,614 , ukuran perusahaan naik 1 satuan maka nilai perusahaan akan turun $-0,141$, dan jika profitabilitas naik 1 satuan maka nilai perusahaan akan naik 14.32.

Tax avoidance memiliki nilai t hitung 0,827 dengan nilai signifikan 0,411 . Nilai t hitung 0,827 lebih kecil dari t tabel 1,98638 dan nilai signifikan 0,411 melebihi 0,05. Sehingga, memiliki arti $\mathrm{H}_{1}$ ditolak dan $\mathrm{H}_{0}$ diterima.

Ukuran perusahaan memiliki nilai t hitung 2,169 dengan nilai signifikan 0,033. Nilai t hitung 2,169 lebih besar dari t tabel 1,98638 dan nilai signifikan 0,033 lebih kecil dari 0,05. Sehingga, memiliki arti $\mathrm{H}_{2}$ diterima $\mathrm{H}_{0}$ ditolak.

Profitabilitas memiliki nilai t hitung 6,703 dengan nilai signifikan 0. Nilai t hitung 6,703 lebih besar dari t tabel 1,98638 dan nilai signifikan 0 lebih kecil dari 0,05. Sehingga, memiliki arti $\mathrm{H}_{3}$ diterima $\mathrm{H}_{0}$ ditolak.

Dari hal tersebut, dapat disimpulkan hubungan antara hubungan tax avoidance terhadap nilai perusahaan secara individual tidak memiliki pengaruh signifikan. Sedangkan, hubungan ukuran perusahaan dan profitabilitas terhadap nilai perusahaan secara individual memiliki pengaruh signifikan.

2. Pengujian hipotesis menggunakan moderated regression analysis a) Uji Koefisien Determinasi (Adjusted $R^{2}$ )

Tabel 11. hasil uji koefesien determinasi (Adjusted $\mathrm{R}^{2}$ )

\begin{tabular}{cccr}
\hline $\mathrm{R}$ & R Square & $\begin{array}{c}\text { Adjusted R } \\
\text { Square }\end{array}$ & \multicolumn{2}{c}{ Std. Error of the Estimate } \\
\hline .721 & 0.52 & 0.481 & 0.69571 \\
\hline
\end{tabular}

Berdasarkan uji koefisien determinasi di atas, memiliki nilai Adjusted $R$ 0,481 atau 48,1\% sisanya $51,9 \%$. Sehingga, dapat disimpulkan bahwa terjadi peningkatan namun tetap saja hanya mampu menjelaskan $48,1 \%$ saja. Sedangkan, $51,9 \%$ dijelaskan oleh variabel lain yang tidak terdapat dalam model regresi ini.

b) Uji F (Simultan)

Tabel 12. hasil uji F

\begin{tabular}{lrrrrr}
\hline & Sum of Squares & \multicolumn{1}{c}{ df } & Mean Square & F & \multicolumn{1}{c}{ Sig. } \\
\cline { 2 - 6 } Regression & 46.054 & 7 & 6.579 & 13.593 & $.000^{\mathrm{b}}$ \\
Residual & 42.593 & 88 & 0.484 & & \\
Total & 88.646 & 95 & & & \\
\hline
\end{tabular}

Berdasarkan uji F pada tabel 4.11, memiliki nilai uji signifikan 0,000. Nilai uji signifikan lebih kecil dari 0,05. Sehingga, model regresi dapat menjelaskan hubungan independen baik sesudah dimoderasi maupun sebelum dimoderasi sangat signifikan terhadap dependen. Semua variabel independenya tax avoidance, ukuran perusahaan, dan profitabilitas dimoderasi ASEAN corporate governance scorecard memiliki pengaruh bersama-sama (Simultan) terhadap nilai perusahaan. Dengan demikian, model dan teori sangat cocok karena sangat sesuai dengan kerangka konseptual. 
c) Uji T (Parsial)

Tabel 13. hasil uji $\mathrm{T}$

\begin{tabular}{lrrrr}
\hline & \multicolumn{1}{c}{ B } & Std. Error & \multicolumn{1}{c}{ T } & \multicolumn{1}{c}{ Sig. } \\
\cline { 2 - 5 } (Constant) & 3.252 & 5.671 & 0.573 & 0.568 \\
Tax avoidance (X1) & 1.468 & 1.441 & 1.019 & 0.311 \\
Ukuran perusahaan (X2) & -0.1 & 0.177 & -0.564 & 0.574 \\
Profitabilitas (X3) & 23.06 & 4.445 & 5.188 & 0 \\
ASEAN corporate governance scorecard $(\mathrm{Z})$ & 2.164 & 6.094 & 0.355 & 0.723 \\
Tax avoidance dan ASEAN corporate & -.0231 & 1.693 & -0.136 & 0.892 \\
governance scorecard (X1*Z) & & & & \\
Ukuran perusahaan dan ASEAN corporate & -0.038 & 0.19 & -0.2 & 0.842 \\
governance scorecard (X2*Z) & & & & \\
Profitabilitas dan ASEAN corporate & -12.057 & 5.116 & -2.357 & 0.021 \\
governance scorecard (X3*Z) & & & & \\
\hline
\end{tabular}

Berdasarkan uji T pada tabel 4.12, mendapatkan persamaan model regresi moderated regression analysis dengan signifikansi $0,05(5 \%)$ sebagai berikut:

Nilai perusahaan $=3,252+1,468 X 1-0.1 X 2+23.06 X 3+2,164 Z-0,0231 X 1 * Z-$ $0,038 X 2 * Z-12,057 X 3 * Z+e$

Nilai konstanta 3,252 tidak akan berubah jika tidak ada perubahan dari variabel independen. Jika naik 1 satuan maka mengikuti konstanta dari variabel itu sendiri.

Tax avoidance memiliki nilai thitung 1,019 dengan nilai signifikan 0,311. Nilai t hitung 1.019 lebih kecil dari t tabel 1,98729 dan nilai signifikan 0,311 lebih besar dari 0,05. Sehingga $\mathrm{H}_{1}$ ditolak $\mathrm{H}_{0}$ diterima.

Ukuran perusahaan memiliki nilai t hitung -0,564 dengan nilai signifikan 0,574. Nilai t hitung 0,564 lebih kecil dari t tabel 1,98729 dan nilai signifikan 0,574 lebih besar dari 0,05. Dikarenakan nilai $\mathrm{t}$ hitung berupa negatif, $\mathrm{t}$ tabelnya diganti dengan one tailed 1,66235. Sehingga, - 0,564 menjadi 0,564 tetap masih kecil dari t tabel itu artinya $\mathrm{H}_{2}$ ditolak $\mathrm{H}_{0}$ diterima.

Profitabilitas mrmiliki nilai t hitung 5,188 dengan nilai signifikan 0. Nilai t hitung 5,188 lebih besar dari $\mathrm{t}$ tabel 1,98729 dan nilai signifikan 0 lebih besar dari 0,05. Sehingga, $\mathrm{H}_{3}$ diterima dan $\mathrm{H}_{0}$ ditolak.

ASEAN corporate governance scorecard memiliki nilai t hitung 0.355 dengan nilai signifikan 0,723 . Nilai t hitung 0,355 lebih kecil dari t tabel 1,98729 dan nilai signifikan 0,723 lebih besar dari 0,05. Sehingga, $\mathrm{H}_{4}$ ditolak dan $\mathrm{H}_{0}$ diterima.

Tax avoidance dan ASEAN corporate governance scorecard memiliki nilai t hitung -0,136 dengan nilai signifikan 0,892 . Nilai t hitung $-0,136$ lebih kecil dari t tabel 1,98729 dan nilai signifikan 0,892 lebih besar dari 0,05. Dikarenakan nilai t hitunng berupa negatif, $t$ tabelnya diganti dengan one tailed 1,66235. Sehingga, $-0,136$ menjadi 0,136 tetap masih lebih kecil dari $\mathrm{t}$ tabel itu artinya $\mathrm{H}_{5}$ diterima dan $\mathrm{H}_{0}$ ditolak.

Ukuran perusahaan dan ASEAN corporate governance scorecard memiliki nilai t hitung $-0,2$ dengan nilai signifikan 0,842 . Nilai t hitung $-0,2$ lebih kecil dari t tabel 1,98729 dan nilai signifikansi 0,842 lebih besar dari 0,05 . Dikarenakan nilai t hitung berupa negatif, $t$ tabelnya diganti dengan one tailed 1,66235.Sehingga, -0,2 menjadi 0,2 tetap masih lebih kecil dari $t$ tabel itu artinya $\mathrm{H}_{6}$ ditolak dan $\mathrm{H}_{0}$ diterima. 
Profitabilitas dan ASEAN corporate governance scorecard memiliki nilai t hitung -2,357 dengan nilai signifikan 0,021. Nilai t hitung -2,357 lebih kecil dari t tabel 1,98729 dengan nilai signifikansi 0,021 lebih kecil dari 0,05 . Dikarenakan nilai $t$ hitung negatif, $t$ tabelnya diganti one tailed 1,66235. Sehingga, -2,357 menjadi 2,357 dan berubah lebih besar dari t tabel itu artinya $\mathrm{H}_{7}$ diterima $\mathrm{H}_{0}$ ditolak.

Dari hal tersebut, dapat disimpulkan hubungan tax avoidance, ukuran perusahaan, tax avoidance setalah dimoderasi dan ukuran perusahaan setelah dimoderasi tidak memiliki pengaruh terhadap nilai perusahaan secara individual. Sedangkan, hubungan antara profitabilitas dan profitabilitas yang sudah dimoderasi terhadap nilai perusahaan memiliki pengaruh secara individual.

2. Pembahasan

a) Pembahasan pertama

Berdasarkan uji koefisien determinasi pada persamaan moderated regression analysis memiliki nilai Adjusted $R$ 0,481 atau 48,1\% sisanya 51,9\% dijelaskan oleh variabel lain yang tidak terdapat dalam model regresi ini.

b) Pembahasan kedua

Berdasarkan hasil penelitian uji $\mathrm{F}$ pada persamaan moderated regression analysis memiliki nilai uji signifikan 0,000. Sehingga, model regresi dapat menjelaskan hubungan independen baik sesudah dimoderasi maupun sebelum dimoderasi sangat signifikan terhadap dependen artinya model cocok.

c) Pembahasan ketiga

1. Pengaruh tax avoidance terhadap nilai perusahaan.

Hasil uji t menunjukkan nilai t statistik tax avoidance 1.019 dengan nilai probabilitas 0,311, maka $\mathrm{H}_{1}$ ditolak dan $\mathrm{H}_{0}$ diterima. Pada nilai koefisien menunjukkan nilai 1,468. Pengaruhnya positif dan tidak signifikan oleh tax avoidance. Penelitian yang sama dilakukan oleh (Sianturi, 2021) tax avoidance dengan nilai perusahaan positif dan tidak signifikan.

2. Pengaruh ukuran perusahaan terhadap nilai perusahaan.

Hasil uji $\mathrm{t}$ menunjukkan nilai $\mathrm{t}$ statistik ukuran perusahaan 0,564 dengan nilai probabilitas 0,574, maka $\mathrm{H}_{2}$ ditolak dan $\mathrm{H}_{0}$ diterima. Pada nilai koefisien menunjukkan nilai -0,1. Pengaruhnya negatif dan tidak signifikan oleh ukuran perusahaan. Penelitian yang dilakukan oleh (Suwardika \& Mustanda, 2017) ukuran perusahaan dengan nilai perusahaan negatif dan tidak signifikan.

3. Pengaruh profitabilitas terhadap nilai perusahaan.

Hasil uji t menunjukkn nilai t statistik profitabilitas 5.188 dengan nilai probabilitas 0 , maka $\mathrm{H}_{3}$ diterima dan $\mathrm{H}_{0}$ ditolak. Pada nilai koefisien menunjukkan nilai 23.06 . Pengaruhnya positif dan signifikan oleh profitabilitas. Penelitian yang yang dilakukan oleh (Martha et al., 2018), (Holly, 2018), (Lumolu et al., 2018), (Hardiningsih et al., 2018), (Mawati et al., 2017), (Nurminda et al., 2017), (Wiksuana \& Wulandari, 2017), (Suwardika \& Mustanda, 2017), (Widyantari \& Yadnya, 2017). Dari hasil penelitianpenelitian tersebut menyatakan nilai perusahaan dipengaruhi secara positif dan signifikan oleh profitabilitas.

4. Pengaruh tax avoidance terhadap nilai perusahaan di moderasi ASEAN corporate governance scorecard.

Hasil uji t menunjukkan nilai t statistik tax avoidance yang dimoderasi ASEAN corporate governance scorecard 0.136 dengan nilai probabilitas 0,892 , maka $\mathrm{H}_{4}$ ditolak dan $\mathrm{H}_{0}$ diterima. Pada nilai koefisien menunjukkan nilai -0,231. Pengaruhnya negatif dan tidak signifikan oleh tax avoidance yang dimoerasi ASEAN corporate governance scorecard. Penelitian yang dilakukan oleh (Sianturi, 2021) menyatakan 
variabel moderasi tidak mampu memoderasi hubungan antara tax avoidance dengan nilai perusahaan positif dan tidak signifikan.

5. Pengaruh ukuran perusahaan terhadap nilai perusahaan di moderasi ASEAN corporate governance scorecard.

Hasil uji t menunjukkan nilai t statistik ukuran perusahaan yang dimoderasi ASEAN corporate governance scorecard 0.2 dengan nilai probabilitas 0,842 , maka $\mathrm{H}_{5}$ ditolak dan $\mathrm{H}_{0}$ diterima. Pada nilai koefisien menunjukkan nilai -0,038. Pengaruhnya secara negatif dan tidak signifikan oleh ukuran perusahaan yang dimoderasi ASEAN corporate governance scorecard. Penelitian yang sama dilakukan oleh (Raharjo, 2016) menyatakan variabel moderasi tidak mampu memoderasi hubungan antara ukuran perusahaan dengan nilai perusahaan.

6. Pengaruh profitabilitas terhadap nilai perusahaan di moderasi ASEAN corporate governance scorecard.

Hasil uji t menunjukkan nilai t statistik profitabilitas 2,357 dengan nilai probabilitas 0,021, maka $\mathrm{H}_{6}$ diterima dan $\mathrm{H}_{0}$ ditolak. Pada nilai koefisien menunjukkan nilai 12,057. Pengaruhnya secara negatif dan signifikan oleh profitabilitas yang dimoderasi ASEAN corporate governance scorecard. Penelitian yang dilakukan oleh menyatakan (Mawati et al., 2017) meyatakan variabel moderasi mampu memoderasi hubungan antara profitabilitas dengan nilai perusahaan.

a) Pembahasan keempat

Berdasarkan hasil penelitian uji koefisien determinasi menunjukkan nilai sebelum ada variabel moderasi 0,438 atau $43,8 \%$. Kemudian, setelah terdapat variabel moderasi dengan persamaan moderated regression analysis menunjukan nilai 0,481 atau $48,1 \%$. Sehinnga, dapat diambil kesimpulan variabel moderasi memperkuat 0,043 atau $4,3 \%$.

\section{KESIMPULAN, KETERBATASAN DAN SARAN}

A. Kesimpulan

1. Berdasarkan hasil analisis dan pembahasan pada bab sebelumnya, dapat disimpulkan bahwa secara parsial tax avoidance berpengaruh positif dan tidak signifikan terhadap nilai perusahaan, ukuran perusahaan berpengaruh negatif dan tidak signifikan terhadap nilai perusahaan, dan profitabilitas berpengaruh positif dan signifikan terhadap nilai perusahaan dalam studi kasus perusahaan lq 45 selama periode 2018-2020. ASEAN corporate governance scorecard tidak mampu memoderasi tax avoidance dan ukuran perusahaan. Namun, ASEAN corporate governance scorecard mampu memoderasi profitabilitas terhadap nilai perusahaan dalam studi kasus perusahaan lq 45 selama periode 2018-2020.

2. Secara simultan tax avoidance, ukuran perusahaan, profitabilitas, tax avoidance yang dimoderasi ASEAN corporate governance scorecard, ukuran perusahaan yang dimoderasi ASEAN corporate governance scorecard, dan profitabilitas yang dimoderasi ASEAN corporate governance scorecard mempengaruhi nilai perusahaan.

3. Variabel moderasi memiliki sifat memperkuat dalam persamaan moderated regression analysis dengan peningkatan 0,043 atau $4,3 \%$.

B. Saran

1. Bagi lembaga keuangan untuk lebih memperhtikan atau mempublikasikan kembali poinpoin yang digunakan untuk mencari nilai dari ASEAN corporate governance scorecard, jika itu dinilai memang sangat penting sebagai tolak ukur perusahaan yang baik.

2. Bagi peneliti, untuk mengganti variabel ASEAN corporate governance scorecard dengan ROA, ROE atau menambah variabel lain dan memperpanjang periode penelitian yang dilakukan untuk mengetahui lebih efektif lagi hasil nilai perusahaan. 
1. Kurang maksimal dalam perhitungan ASEAN corporate governance scorecard, dikarenakan kurangnya publikasi mengenai poin-poin yang dicari untuk bisa menilai ASEAN corporate governance scorecard tersebut.

\section{REFERENSI}

Ambarwati, \& Kabib, N. (2021). Pengaruh Pendidikan Keluarga, Pendidikan Sekolah, Pendidikan Masyarakat Terhadap Ahklak Siswa Sekolah Menegah atas di Kabupaten Klaten Tahun 2021. JIIP - Jurnal Ilmiah Ilmu Pendidikan, 4(6), 462-471. https://doi.org/10.54371/jiip.v4i6.306

Azhar, R. (2017). Tax Avoidance Terhadap Nilai Perusahaan dan Agency Cost Dengan Kepemilikan Institusional Sebagai Variabel Moderating. Skripsi Syarif Hidayatullah Jakarta, 108.

Dewi, R. (2021). 15 Perusahaan Ritel Terbesar Asia Tenggara 2021, Ada Tokopedia hingga Bukalapak.

Www.Kompas.Com. https://www.kompas.com/tren/read/2021/10/10/163000265/15-perusahaan-ritel-terbesar-asiatenggara-2021-ada-tokopedia-hingga?page=all

Hardiningsih, P., Fatmawati, T., \& Srimindarti, C. (2018). Kontijensi Good Corporate Governance Dalam Determinan Nilai Perusahaan. Prosiding SENDI_U, 4(2015), 608-615.

Holly, A. (2018). Determinan Nilai Perusahaan Di Bursa Efek Indonesia. SiMAk, 16(02), 101-118. https://doi.org/10.35129/simak.v16i02.44

Inanda, T., Suranta, E., \& Midiastuty, P. (2018). Pengaruh Penghindaran Pajak Terhadap Nilai Perusahaan Yang Dimoderasi Oleh Corporate Governance Dan Kepemilikan Mayoritas. Jurnal Akuntansi, 12(2), 126-145. https://doi.org/10.25170/jara.v12i2.85

Israel, C. (2018). Pengaruh Struktur Modal, Kepemilikan Institusional Dan Ukuran Perusahaan Terhadap Nilai Perusahaan Pada Perusahaan Pertambangan Yang Terdaftar di BEI. Jurnal EMBA: Jurnal Riset Ekonomi, Manajemen, Bisnis Dan Akuntansi, 6(3), 1118-1127. https://doi.org/10.35794/emba.v6i3.20073

Kusna, I., \& Setijani, E. (2018). Analisis Pengaruh Kinerja Keuangan , Growth Opportunity Dan Ukuran Perusahaan Terhadap Struktur Modal Dan Nilai Perusahaan. Jurnal Manajemen Dan Kewirausahaan, 6(1), 93-102.

Lumolu, S., Murni, S., \& Untu, V. (2018). Pengaruh Likuiditas, Ukuran Perusahaan dan Profitabilitas Terhadap Nilai Perusahaan (Studi pada Perusahaan Logam dan Sejenisnya yang Terdaftar di Bursa Efek Indonesia). Jurnal EMBA, 6(3), 1108-1117.

Martha, L., Sogiroh, N., Magdalena, M., Susanti, F., \& Syafitri, Y. (2018). Profitabilitas dan Kebijakan Dividen Terhadap nilai Perusahaan. Jurnal Benefita, 3(2), 227-238. http://ejournal.lldikti10.id/index.php/benefita/article/view/3493

Mawati, E. R., Hardiningsih, P., \& Srimindarti, C. (2017). Corporate governance memoderasi earnings management dan profitabilitas terhadap nilai perusahaan. unisbank.ac.id. https://www.unisbank.ac.id/ojs/index.php/sendi_u/article/view/5023

Nurminda, A., Isynuwardhana, D., \& Nurbaiti, A. (2017). Pengaruh Profitabilitas, Leverage, dan Ukuran Perusahaan Terhadap Nilai Perusahaan (Studi pada Perusahaan Manufaktur Sub Sektor Barang dan Konsumsi yang Terdaftar di Bursa Efek Indonesia Periode 2012-2015 ). 4(1), 542-549.

Putra, A. (2018). Role of ASEAN Corporate Governance Scorecard in Relationship Between 
Accounting, 9(8), 160-170. https://core.ac.uk/download/pdf/234632319.pdf

Raharjo, P. (2016). Pengaruh Keputusan Pendanaan dan Ukuran Perusahaan Terhadap Nilai Perusahaan Dengan Kebijakan Dividen Sebagai Variabel Moderasi. 14-16.

Rajagukguk, B., Joharindu, V., \& Adi, P. (2020). Pengaruh Tax Avoidance Dan Kinerja Keuangan Terhadap Nilai Perusahaan Dengan Kepemilikan Institusional Sebagai Pemoderasi. Jurnal $\begin{array}{llrr}\text { Akuntansi \& } & \text { Ekonomi, } & 5(2), & \text { 58-70. }\end{array}$ http://jurnalmahasiswa.stiesia.ac.id/index.php/jira/article/view/1032

Sianturi, D. (2021). Pengaruh Tax Avoidance Terhadap Nilai Perusahaan Dan Cost Of Debt Dengan Transparansi Informasi Sebagai Variabel Pemoderasi Pada Perusahaan Perkebunan Yang Terdaftar Di Bei Periode 2011-2015. Jurnal Pembangunan Wilayah \& Kota, 1(3), 8291.

Suwardika, \& Mustanda. (2017). Pengaruh Leverage, Ukuran Perusahaan, Pertumbuhan Perusahaan, Dan Profitabilitas Terhadap Nilai Perusahaan Pada Perusahaan Properti. E-Jurnal Manajemen Universitas Udayana, 6(3), 1248-1277.

Wardani, D., \& Juliani. (2018). The Effect Of Tax Avoidance On Company Value With Corporate Governance As Moderating Variables. Jurnal Nominal / Volume VII Nomor 2 / Tahun 2018, $\operatorname{VII}(02), 47-61$.

Wasista, \& Putra. (2019). Pengaruh Profitabilitas dan Ukuran Perusahaan Pada Nilai Perusahaan Dengan Good Corporate Governance Sebagai Variabel Pemoderasi. E-Jurnal Akuntansi, 29(3), 928-942. https://doi.org/10.24843/eja.2019.v29.i03.p02

Widyantari, \& Yadnya. (2017). Pengaruh Struktur Modal, Profitabilitas Dan Ukuran Perusahaan Terhada Nilai Perusahaan Pada Perusahaan Food Bavaerage Di Bursa Efek Indonesia. EJurnal Manajemen Universitas Udayana, 6(12), 6383-6409.

Wiksuana, \& Wulandari. (2017). Peranan Corporate Social Responbility Dalam Memoderasi Pengaruh Profitabilitas, Leverage Dan Ukuran Perusahaan Terhadap Nilai Perusahaan. EJurnal Manajemen Universitas Udayana, 6(3), 1278-1311.

Yee, C., Sapiei, N., \& Abdullah, M. (2018). Tax Avoidance, Corporate Governance and Firm Value in The Digital Era. Journal of Accounting and Investment, 19(2), 160-175. https://doi.org/10.18196/jai.190299

Zoebaedi, F., \& Warsono. (2019). Determinan Nilai Perusahaan Dengan Struktur Modal Sebagai Variabel Intervening pada Perusahaan LQ 45 Di Indonesia. JRB-Jurnal Riset Bisnis, 3(1), 3753. http://journal.univpancasila.ac.id/index.php/jrb/article/view/979 